\title{
"The relation between product market competition and corporate tax avoidance: evidence from Korea"
}

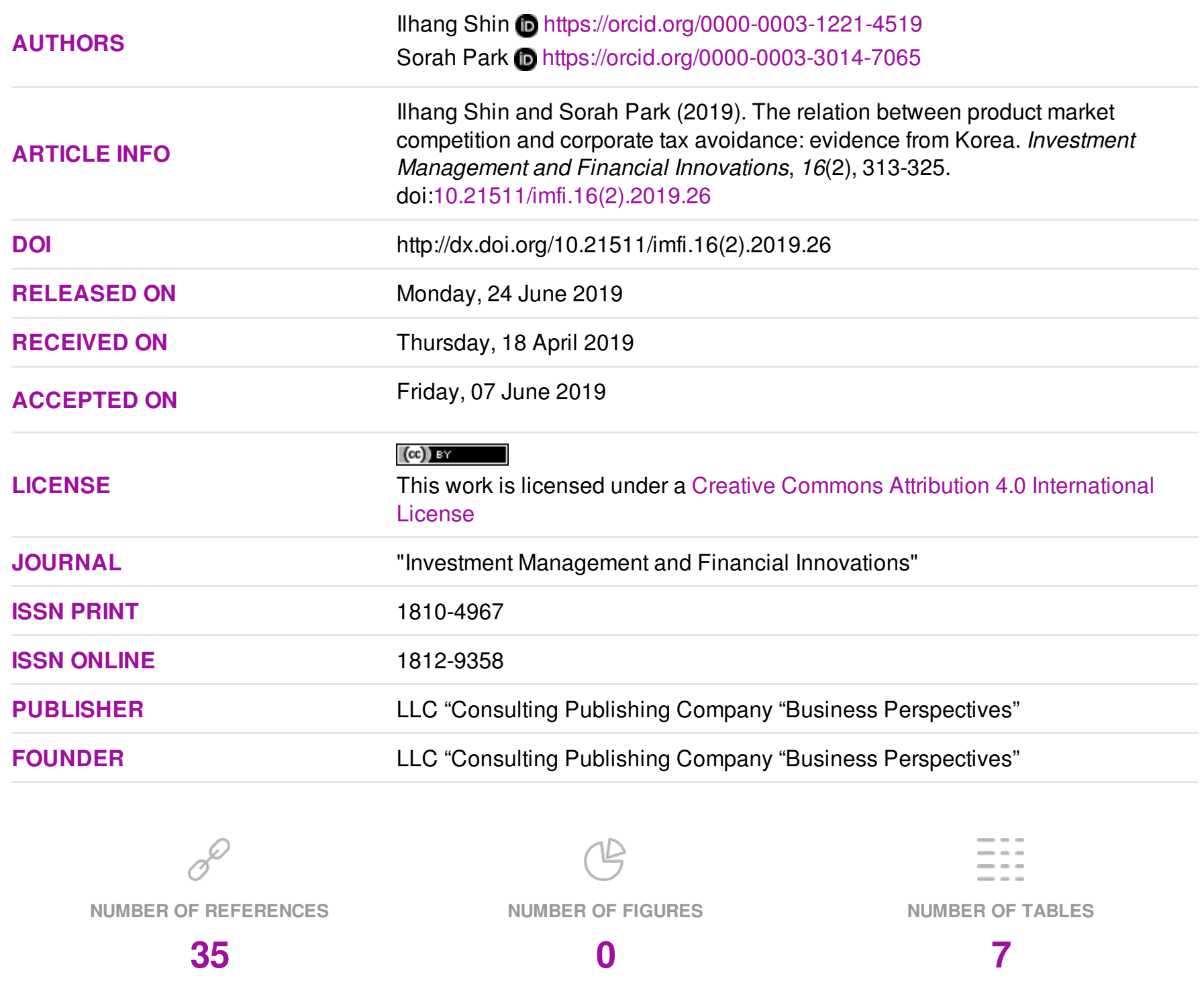

(C) The author(s) 2023. This publication is an open access article. 


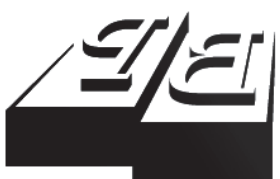

BUSINESS PERSPECTIVES

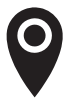

LLC "CPC "Business Perspectives" Hryhorii Skovoroda lane, 10, Sumy, 40022, Ukraine

www.businessperspectives.org

Received on: $18^{\text {th }}$ of April, 2019 Accepted on: $7^{\text {th }}$ of June, 2019

(C) Ilhang Shin, Sorah Park, 2019

Ilhang Shin, Assistant Professor of Accounting Gachon University, Seongnam-si, Gyunggi-do, Korea.

Sorah Park, Associate Professor of Accounting Ewha Womans University, Seoul, Korea.

\section{() (i)}

This is an Open Access article, distributed under the terms of the Creative Commons Attribution 4.0 International license, which permits unrestricted re-use, distribution, and reproduction in any medium, provided the original work is properly cited.

\title{
THE RELATION BETWEEN PRODUCT MARKET COMPETITION AND CORPORATE TAX AVOIDANCE: EVIDENCE FROM KOREA
}

\begin{abstract}
This paper examines the effect of industry-wide factors such as product market competition on corporate tax avoidance. Specifically, the focus is on the moderating role of corporate governance in the relationship between product market competition and tax avoidance. To conduct an empirical analysis, a sample of public companies that are listed on the Korea Stock Exchange between 2001 and 2016 is used. The empirical analyses provide the following results. First, product market competition is negatively related to tax avoidance. This suggests that competitive markets act as external corporate governance mechanisms and discipline managers to decrease tax avoidance. Second, the negative association between product market competition and tax avoidance is more pronounced for firms with more independent board of directors and firms with audit committee consisting of outside directors. These findings imply that product market competition acts more effectively when the firm has strong internal governance mechanisms such as board independence and audit committee independence. Therefore, we provide evidence on a complementary relationship between internal governance system and product market competition. The results may be of interest to policy makers and regulators like Korea Fair Trade Commission and Financial Supervisory Service who are involved in promoting market competition, monitoring any abuse of market dominance, and supervising financial reporting quality.
\end{abstract}

\section{Keywords}

\section{JEL Classification}

\section{INTRODUCTION}

A corporation or a limited company is a business entity characterized by the separation of ownership from management that aims to maximize expertise and efficiency. Alignment of the interests of the owners and managers ensures that the first-best outcome is attained and zero agency cost is incurred. However, misalignment of incentives between owners and managers (combined with information asymmetry) would cause the agency problem (Jensen \& Meckling, 1992).

Corporate governance system influences management behavior in order to mitigate the agency problem caused by the separation of ownership and management and to guarantee that the company achieves its strategic goals. Internal governance mechanisms help in monitoring the activities of the management and introducing corrective measures when the business goes off track. These mechanisms include the board of directors (BOD), insider ownership, and incentive compensation. External governance mechanisms are imposed by external stakeholders such as institutional investors and major shareholders of the com- 
pany, and the markets for managerial labor, corporate control, and products. Specifically, product market competition has been documented to be an effective external governance mechanism that reduces information asymmetry and agency problem (Shleifer \& Vishny, 1997; Grullon \& Michaely, 2007).

We now shift our attention to corporate tax avoidance. This behavior could be a legal avoidance or an illegal evasion that results in violation or abuse of tax laws. Legal tax planning is critical from a strategic perspective since it could reduce the corporate tax liability. While tax avoidance activities have positive effects on current cash flows, they could negatively affect firm value, because these activities deteriorate the credibility of financial reporting information and increase the probability of detecting a diversion for private gain and consequently increase future cash outflows for tax amount paid in tax audit (Slemrod, 2007; Hanlon \& Heitzman, 2010).

Previous studies indicate that stringent enforcement actions undertaken by tax authorities limit managerial opportunistic behavior (Desai et al., 2007) and that lower tax avoidance is associated with stronger corporate governance (Desai et al., 2004). However, although numerous studies have examined the effect of firm-level internal corporate governance mechanisms on tax avoidance, the relationship between external governance mechanisms and tax avoidance has received relatively limited attention.

Therefore, this paper investigates the manner in which product market competition works as an external corporate governance system in decreasing corporate tax avoidance. Moreover, we examine how the relationship between product market competition and tax avoidance is affected by various internal corporate governance mechanisms as follows: (1) independence of board of directors, (2) audit committee, (3) independence of audit committee members, (4) foreign investor ownership.

To conduct an empirical analysis, we use a sample of public companies that are listed on the Korea Stock Exchange between 2001 and 2016. An advantage of focusing on the Korean stock market is that we can control for the effect of other external corporate governance mechanisms on the relationship between product market competition and corporate tax avoidance. Among many external governance mechanisms, markets for managerial labor and corporate control are known to be weak in Korea (Lemmon \& Lin, 2003). On the other hand, product market competition is an effective operating factor that ensures market discipline in Korea (Black et al., 2006). Thus, investigating how managerial behavior is influenced by product market competition using Korean data could enable us to control for other corporate governance mechanisms. As a result, this will minimize the endogeneity problem and ensure a valid inference about the effect of product market competition on tax avoidance.

The main findings of this paper are as follows. First, we find a negative association between the level of product market competition and corporate tax avoidance. This suggests that competitive markets, acting as external corporate governance mechanisms, discipline managers to decrease tax avoidance. Second, we find that the negative association between product market competition and tax avoidance is more pronounced for firms with more independent board of directors than for firms with less independent board. Third, the negative relationship between product market competition and tax avoidance is stronger for firms with independent audit committees. However, we find that foreign investor ownership has no significant influence on the association between product market competition and tax avoidance. These findings indicate that product market competition acts more effectively when the firm has strong internal governance mechanisms such as an independent board of directors and audit committee. Hence, we provide evidence on a complementary relationship between internal governance system and product market competition.

This paper offers several contributions that differentiate it from previous studies. First, this study is the first to examine how the industry-wide factor such as product market competition affects the corporate tax avoidance activity, while many previous studies have focused on firm-specific characteristics as the determinants of corporate tax avoidance. Second, the findings of this paper directly correspond to the 
question regarding the effect of government regulations and policies on corporate tax avoidance. We find that increased competition in product markets reduces corporate tax avoidance activities and related agency costs. Therefore, our results may be of interest to policy makers and regulators, such as Korea Fair Trade Commission and Financial Supervisory Service, involved in promoting market competition, monitoring any abuse of market dominance, and supervising financial reporting quality.

The remainder of this paper is organized as follows. Section 1 reviews the related literature on product market competition and tax avoidance and develops the hypotheses. Section 2 discusses the empirical methodologies, and Section 3 discusses the test results. Finally, last section concludes the paper by discussing the implications of our research.

\section{LITERATURE REVIEW AND HYPOTHESES DEVELOPMENT}

\subsection{Product market competition}

Numerous studies consider the effect of product market competition on the agency problem caused by information asymmetry. La Porta et al. (2000) argue that, in case of intense product market competition, management may prefer to distribute cash to shareholders due to high risk of liquidation. Moreover, Ryu and Byun (2012) document a negative relationship between corporate payout policy (including share repurchases) and product market competition in the Korean stock market. Furthermore, they show that both industry concentration and industry leader are negatively associated with total payout ratio (scaled by market value), suggesting that corporate dividend policy is induced to reduce agency costs. Therefore, agency problems will be mitigated by the efforts made to reduce the probability of liquidation and competitor threats (La Porta et al., 2000; Park et al., 2011).

Also, numerous studies have previously examined the relation between product market competition and firm performance. Based on a study in the UK, Nickell (1996) shows that higher competition, either due to lower entry barriers or more competitors, is related to higher productivity growth. Hay and Liu (1997), based on their empirical analysis of 19 companies within the manufacturing sector in the UK, argue that "in highly competitive markets, only the most efficient firms will survive. In less competitive markets, less efficient firms may be able to maintain substantial market shares in protected market segments (p. 614)". Chhaochharia et al. (2009) find that the product market competition mitigates the agency problem and that the efficiency is lower for firms in less competitive markets, compared to firms in more competitive markets.

Comprehensively, market monitoring could mitigate agency problems, since it reduces managers' discretionary power to extract private benefits. Therefore, product market competition acts as an external governance mechanism, thereby having a regulatory effect on the market (Fama, 1980; Fama \& Jensen, 1983; Shleifer \& Vishny, 1997; Allen \& Gale, 2000; Haushalter et al., 2006; Grullon \& Michaely, 2007; Datta et al., 2013; Song, 2013).

\subsection{Corporate tax avoidance}

Companies have a duty to pay corporate tax as a proportion of earnings generated from their operating activities during the fiscal period. "Because the income tax expense is an accrual-based expense, portions of it can potentially be manipulated to affect after-tax earnings (Hanlon \& Heitzman, 2010, p. 130)". Tax avoidance is any business activity that reduces the effective tax rate of a firm, in relation to its pre-tax income (Dyreng et al., 2008) ${ }^{1}$.

Income tax expense affects cash outflows. Tax avoidance activities reduce tax liabilities, thereby

1 Tax avoidance could be broadly defined as legal tax planning and illegal tax evasion (e.g., Hanlon \& Heitzman, 2010). Legal tax planning, including tax credits and tax reduction system, decreases tax burden within the confines of tax law. On the other hand, illegal tax evasion includes deleting revenues, recognizing expenses where there is no real transaction, over-stating expenses, etc. This intentionally reduces national finance, thus imposing additional tax burden on others or inducing higher tax rates. If detected, companies will be charged with unpaid or additional taxes, as well as criminal punishment. This paper defines tax avoidance as legal tax planning in a narrow sense. 
increasing the corporate cash holdings. However, when there exists information asymmetry between managers and shareholders, conflicts between the two parties could arise due to a failure of utilizing the increased after-tax wealth for shareholder value. Particularly, tax avoidance will result in an adverse effect when the marginal costs exceed the marginal benefits.

According to prior research (Desai et al., 2004; Desai \& Dharmapala, 2006), benefits and costs of tax avoidance depend on corporate governance. In widely-held corporations, where the ownership and the management are separated, managers could exploit corporate resources for private gains. Such agency problems may be aggravated due to the information asymmetry between management and shareholders. Desai et al. (2004) find that corporate governance is negatively related to tax avoidance. This suggests that firms with strong corporate governance structure and external shareholder monitoring have high corporate transparency. Hence, the probability for managers to divert increased after-tax wealth obtained from tax avoidance for their private gains will be lower. Furthermore, Slemrod (2007) suggests that the design of incentive plans could influence corporate tax avoidance. Desai and Dharmapala (2006), Rego and Wilson (2012) document a negative relationship between top executives' equity-based compensation and tax avoidance. Moreover, Armstrong et al. (2012) show that the compensation of a tax director is negatively associated with the GAAP effective tax rate (i.e., the extent of a firm's tax planning). When managers engage in tax avoidance for private gains, increased equity incentives will further align their incentives with shareholders, which will ultimately reduce managerial diversion and tax avoidance.

In accordance with mixed evidence in previous studies, Armstrong et al. (2012) find no relationship between various corporate governance mechanisms and tax avoidance on average. However, they show a positive (negative) relationship between board independence and financial sophistication for low (high) levels of tax avoidance. These findings suggest that extreme levels of tax avoidance are strongly tied to certain attributes of corporate governance.
Furthermore, ownership structure is significantly related to corporate tax avoidance. According to Chen et al. (2010), firms with concentrated ownership (i.e., family-owned firms) are less inclined to avoid taxes compared to non-family firms, since owner families may forgo tax benefits in order to avoid skepticism of minority shareholders. McGuire et al. (2014) state that the level of tax avoidance decreases with the difference between voting rights and cash flow rights, which is consistent with dual class ownership encouraging managers to divert corporate resources.

Numerous studies have been conducted in Korea on the same issue. Based on a sample of listed companies between 2000 and 2006, Koh (2006) shows a positive relationship between tax avoidance and various firm-specific characteristics such as tax burdens (marginal tax rate), profitability (ROE), leverage, and owner-controlled firms. Also, Choi (2007) finds a negative association between tax avoidance and corporate governance during the sample period from 2003 to 2006 . This study specifically shows that strong shareholder rights could lead to a reduction in tax avoidance activities. Furthermore, Oh and Kim (2010) examine the effect of ownership structure on tax avoidance. Based on non-financial companies listed on the Korean Stock Exchange between 2002 and 2008, they find that when the rate of major shareholder's equity is divided into three categories: $1-20 \%, 20-50 \%$, and more than $50 \%$, a significantly positive relationship with tax avoidance is observed in the first and the second categories. Moreover, they show that foreign ownership is negatively related to tax avoidance.

Altogether, previous studies on tax avoidance have focused on firm-specific characteristics, including internal governance mechanisms. By contrast, the effects of industry-wide characteristics such as product market competition (or industry concentration) on tax avoidance have received little attention so far. Therefore, this study can be differentiated from previous studies, as it investigates several hypotheses on the effect of product market competition on tax avoidance.

\subsection{Hypotheses development}

Product market can be described as where goods and services are sold by businesses and bought by 
households, at equilibrium prices determined according to the principle of free competition. The underlying drive for market economy is competition among businesses in order to maximize their profits. It is well established that product market competition encourages managers to reduce slack, since it makes their job less secure (Hart, 1983; Schmidt, 1997; Griffith, 2001). Moreover, Chhaochharia et al. (2009) find that product market competition mitigates agency conflicts, and that firms in less competitive industries are less efficient than those in more competitive industries. Many studies (Shleifer \& Vishny, 1997; Dyck \& Zingales, 2004, Chen et al., 2009; Park et al., 2011; Shin et al., 2014) suggest that product market competition could reduce information asymmetry and agency problems as an external governance mechanism. This implies that product market competition will be negatively related to tax avoidance activities as a means of managerial diversion for private gains. Therefore, we state our first hypothesis as follows:

H1: There is a negative relationship between product market competition and corporate tax avoidance.

Product market competition enhances the quantity and quality of information provided to the public, thereby decreasing the transaction costs for external investors (Holmstrom, 1982; Hart, 1983). It also encourages managers to reduce slack and eventually to adopt an optimal corporate governance system (Alchian, 1950; Stigler, 1958). As suggested by Shleifer and Vishny (1997), there is a complementary relationship between external and internal corporate governance mechanisms and the interaction of these mechanisms could mitigate agency problems by enabling more efficient monitoring of management.

Previous studies (e.g., Byun et al., 2012) imply that a prerequisite for product market competition to effectively monitor managerial diversion is a strong internal governance mechanism. In particular, board of directors, which is a body of elected or appointed members who supervise the management, is considered an essential part of internal governance mechanisms. Moreover, recent studies shed light on the role of audit committee within the corporate board. As more independent directors serve on the audit committee, monitor- ing of managerial opportunism will be more effective. Hence, we propose the following hypothesis considering a complementary relationship between internal and external corporate governance mechanisms:

\section{H2: The negative relationship between product market competition and tax avoidance is more pronounced for firms with strong internal cor- porate governance mechanisms than others.}

\section{RESEARCH DESIGN}

\subsection{Measures of product market competition}

The key variable of this paper is product market competition. Assuming an inverse relationship between product market competition and industry concentration, we use the HerfindahlHerschman Index (HHI hereafter) as a proxy for industry concentration.

We calculate HHI by adding up the squares of the individual market shares (individual firm's sales divided by industry total sales) in the industry. We use the three-digit KSIC code for industry classification. In order to calculate industry total sales, we include public firms listed on KOSPI and KOSDAQ, as well as private firms that are externally audited (Grullon \& Michaely, 2007; Giroud \& Mueller, 2011; Shin et al., 2014). Private firms with total assets of greater than ten million KRW are subject to external audit by government regulations. Hence, our HHI could reflect the industry structure more accurately by including public and major non-listed companies in the calculation.

\subsection{Measures of tax avoidance}

Measuring tax avoidance is difficult, since information regarding corporate tax returns is not publicly available. Numerous studies have attempted to develop tax avoidance measures (e.g., Manzon \& Plesko, 2002; Desai \& Dharmapala, 2006; Dyreng et al., 2008). This study follows Desai and Dharmapala (2006) to measure tax avoidance.

First, we calculate the corporate taxable income by dividing the firm's reported current tax expense 
by the statutory tax rate (Manzon \& Plesko, 2002). Next, we calculate the difference between accounting earnings (pre-tax income) and estimated taxable income. Here, since firms with taxable income of 0 or a negative taxable income have little incentives for tax avoidance, we use a sample consisting of firms with positive taxable income.

As previously stated, it is assumed that book-tax difference that is not accounted by earnings management contains corporate tax avoidance. This means that the portion of book-tax difference due to earnings management should be excluded in order to estimate tax avoidance. Hence, abnormal book-tax difference is measured by the residuals from the regression of total book-tax difference on total accruals (Desai \& Dharmapala, 2006). In addition, the results do not change when using discretionary accruals as a proxy for earnings management, instead of total accruals.

This paper uses discretionary accruals, which is considered a more accurate proxy for earnings management in the literature, in the following regression equation (1) at industry-year level. The residual TA1 is used as proxy to calculate the tax avoidance. The residual TA2 is another proxy for tax avoidance when using total accruals as the earnings management.

$$
B T D_{i t}=\beta_{1} D A_{i t}\left(\text { or } T A_{i t}\right)+\varepsilon_{i t},
$$

where $B T D$ - the difference between book and taxable incomes/beginning total assets, $D A$ - discretionary accruals/beginning total assets, $T A$ total accruals/beginning total assets, $\varepsilon$ residuals proxy for tax avoidance (TA1,TA2).

\subsection{Model specifications}

We use the following model (2) for testing our hypotheses:

$$
\begin{aligned}
& \text { TA1 }(\text { TA2 })=\beta_{0}+\beta_{1} \text { COMPETITION }+ \\
& +\beta_{2} \text { SIZE }+\beta_{3} L E V E R A G E+\beta_{4} \text { ROA }+ \\
& +\beta_{5} I N V E S T+\beta_{6} D A+ \\
& +\beta_{7} \text { CASHHOLDING }+\beta_{8} G R W A+ \\
& +\beta_{9} \text { GRWL }+\beta_{10} \text { FOR }+ \\
& +\sum Y R+\sum I N D+\varepsilon,
\end{aligned}
$$

where TA1, TA2 - tax avoidance proxies, COMPETITION - product market competition, measured by $-1 \cdot H H I, S I Z E$ - natural logarithm of total assets, LEVERAGE - total liabilities/beginning total assets, INVEST - (Change in PPE excluding land + Depreciation $+\mathrm{R} \& \mathrm{D}$ expenditures)/beginning total assets, $D A$ - discretionary accruals (Kothari, 2005), CASHHOLDING

- (Cash and cash equivalents + Short-term investments)/beginning total assets, GRWA - growth rates in total assets relative to prior year, $G R W L$ growth rates in total liabilities relative to prior year, $F O R$ - equity ownership of foreign investors, $Y R$ - year indicators, and $I N D$ - industry indicators.

The dependent variable in equation (2) is the measure of tax avoidance (Desai \& Dharmapala, 2006). A key variable of interest is the product market competition (COMPETITION). The purpose of equation (2) is to examine the relationship between product market competition and tax avoidance. We expect a significantly negative coefficient for COMPETITION, if the product market competition reduces tax avoidance.

We include several control variables in the model based on previous studies. First, natural logarithm of total assets (SIZE) is included to control the effect of firm size. Leverage is included, because highly levered firms have debt tax shields; therefore, they prefer not to use tax avoidance as non-debt tax shields (DeAngelo \& Masculis, 1980; Schallheim \& Wells, 2004; Jeon, 2004; Graham \& Tucker, 2006). Furthermore, since high profitability results in greater incentives to reduce the current period tax burden, we include return on assets $(R O A)$ in order to control the effects of corporate profitability. The Korean taxation laws provide tax benefits for investment in depreciable assets and R\&D; therefore, we include INVEST in the model, since the tax reduction would be higher for higher level of investment. Next, we control the effect of earnings management on tax avoidance by including $D A$ in the model. Firms with low cash holdings will be more inclined to engage in tax avoidance, thus CASHHOLDING is included (Park \& Hong, 2009). According to Kim and Jung (2006), apart from the size of total assets and liabilities, the growth rates of assets and liabilities (GRWA, GRWL) are also related to tax avoidance. Additionally, ownership of foreign investors (FOR) is included, since foreign 
investors tend to monitor corporate tax avoidance activities (Park \& Hong, 2009). Finally, we also include year and industry dummy variables in order to control the differences in accounting and tax regulations across years and industries (Kim \& Jung, 2006). All standard errors are adjusted for firm-level clustering to mitigate potential autocorrelation problems (Petersen, 2009).

\subsection{Sample selection procedure}

The sample used in this paper is based on listed companies on the Korean Stock Exchange between 2001 and 2016. We exclude companies in the financial industry in which different financial reporting standards are imposed. Moreover, we exclude non-December fiscal year-end companies in order to reduce the effect of fiscal year-end month. Firms with capital impairment are excluded in order to reduce the sampling bias. We obtain financial information and stock price data from KIS-VALUE database provided by FnGuide. After deleting firms with missing financial data, final sample consists of 7,918 firm-year observations. Our sampling procedure is summarized in Table 1.

Table 1. Sample selection procedure

\begin{tabular}{l|c}
\hline \multicolumn{1}{c|}{ Sample } & No. of observations \\
\hline Firms listed in KOSPI & 11,717 \\
\hline Less: Financial firms & $(684)$ \\
Less: Firms with non-December & $(301)$ \\
fiscal year-end & $(2,814)$ \\
Less: Firms whose financial data is \\
not available
\end{tabular}

\section{EMPIRICAL RESULTS}

\subsection{Descriptive statistics}

We report the descriptive statistics of test variables in Table 2. The mean and median of COMPETITION are -0.1219 and -0.0720 , respectively. The distribution of COMPETITION appears to be skewed to the left; however, the dispersion of the variable such as $25 \%$ percentile $(-0.1674)$, $75 \%$ percentile $(-0.0343)$, and standard deviation (0.1244) suggests a normal distribution.

Sample firms have a size of 18.9085 , leverage of 0.4387 , and ROA of 0.0378 , on average. Assets and liabilities of sample firms increase at a rate of around $8 \%$, compared to prior year. The mean value of equity ownership ratio held by foreign investors in the sample is $10 \%$. Also, on average, $29.54 \%$ of board members of our sample firms are outside directors. Finally, $27.30 \%$ of sample firms have audit committees, and $24 \%$ of these committees consist of $100 \%$ outside directors.

We report the correlation coefficients of test variables in Table 3. COMPETITION is negatively correlated with firm size $(-0.261)$, leverage $(-0.108)$, investment in depreciable assets and R\&D (-0.040), and foreign investor ownership (-0.18). Moreover, there is a positive correlation between product market competition and discretionary accruals (0.048) and corporate cash holdings (0.014).

Table 2. Descriptive statistics

\begin{tabular}{|c|c|c|c|c|c|c|}
\hline Variable & $\mathbf{N}$ & Mean & Standard deviation & Median & $25 \%$ & $75 \%$ \\
\hline COMPETITION $_{\text {it }}$ & 7.918 & -0.1219 & 0.1244 & -0.0720 & -0.1674 & -0.0343 \\
\hline TA1it & 7.918 & 0.0028 & 0.0740 & 0.0009 & -0.0294 & 0.0295 \\
\hline TA2it & 7.918 & 0.0100 & 0.0727 & 0.0078 & -0.0202 & 0.0357 \\
\hline $\mathrm{SIZE}_{\mathrm{it}}$ & 7.918 & 18.9085 & 1.7251 & 18.5959 & 17.6579 & 19.8545 \\
\hline LEVERAGE $_{i t}$ & 7.918 & 0.4387 & 0.1950 & 0.4396 & 0.2886 & 0.5782 \\
\hline $\mathrm{ROA}_{\mathrm{it}}$ & 7.918 & 0.0378 & 0.0746 & 0.0367 & 0.0088 & 0.0737 \\
\hline INVEST $_{i t}$ & 7.918 & 0.0208 & 0.0541 & 0.0085 & -0.0040 & 0.0344 \\
\hline DAit-1 & 7.918 & 0.0040 & 0.0822 & 0.0051 & -0.0356 & 0.0451 \\
\hline CASHHOLDING $_{i t}$ & 7.918 & 0.0603 & 0.0673 & 0.0377 & 0.0131 & 0.0818 \\
\hline GRWA $_{\text {it }}$ & 7.918 & 0.0750 & 0.1789 & 0.0470 & -0.0159 & 0.1317 \\
\hline$G R W L_{i t}$ & 7.918 & 0.0813 & 0.3238 & 0.0256 & -0.0863 & 0.1766 \\
\hline $\mathrm{FOR}_{\mathrm{it}}$ & 7.918 & 0.1031 & 0.1415 & 0.0373 & 0.0054 & 0.1468 \\
\hline OutsideDir $_{\text {it. }}$ & 7.918 & 0.2954 & 0.1626 & 0.2500 & 0.2000 & 0.4000 \\
\hline AuditCommittee $_{\text {it }}$ & 7.918 & 0.2730 & 0.4456 & 0.0000 & 0.0000 & 1.0000 \\
\hline AuditCom_indepen $_{\text {it }}$ & 7.918 & 0.2397 & 0.4269 & 0.0000 & 0.0000 & 0.0000 \\
\hline
\end{tabular}


Table 3. Correlations ( $p$-values below)

\begin{tabular}{|c|c|c|c|c|c|c|c|c|c|c|c|c|c|c|}
\hline Variable & (2) & (3) & (4) & (5) & (6) & (7) & (8) & (9) & (10) & (11) & (12) & (13) & (14) & $\begin{array}{c}\text { AuditCom } \\
\text { indepen } \\
\text { (15) }\end{array}$ \\
\hline \multirow{2}{*}{ COMPETITION $_{i t}(1)$} & -0.042 & -0.041 & -0.261 & -0.108 & -0.014 & -0.040 & 0.048 & 0.014 & -0.014 & -0.012 & -0.180 & -0.184 & -0.182 & -0.182 \\
\hline & $(0.000)$ & $(0.000)$ & $<.0001$ & $<.0001$ & $(0.214)$ & $(0.000)$ & $<.0001$ & $(0.210)$ & $(0.217)$ & $(0.283)$ & $<.0001$ & $<.0001$ & $<.0001$ & $<.0001$ \\
\hline \multirow{2}{*}{$T A 1_{i t}(2)$} & - & 0.969 & 0.072 & -0.125 & 0.425 & 0.113 & -0.017 & 0.082 & 0.355 & 0.085 & 0.052 & 0.005 & 0.021 & 0.023 \\
\hline & - & $<.0001$ & $<.0001$ & $<.0001$ & $<.0001$ & $<.0001$ & $(0.131)$ & $<.0001$ & $<.0001$ & $<.0001$ & $<.0001$ & $(0.632)$ & $(0.061)$ & $(0.039)$ \\
\hline \multirow{2}{*}{$T A 2_{i t}(3)$} & - & - & 0.075 & -0.116 & 0.422 & 0.122 & 0.059 & 0.072 & 0.355 & 0.085 & 0.052 & 0.008 & 0.023 & 0.027 \\
\hline & - & - & $<.0001$ & $<.0001$ & $<.0001$ & $<.0001$ & $<.0001$ & $<.0001$ & $<.0001$ & $<.0001$ & $<.0001$ & $(0.475)$ & $(0.040)$ & $(0.017)$ \\
\hline \multirow{2}{*}{$\operatorname{SIZE}_{i t}(4)$} & - & - & - & -0.044 & 0.258 & 0.180 & 0.000 & 0.068 & 0.126 & 0.048 & 0.561 & 0.532 & 0.547 & 0.556 \\
\hline & - & - & - & $(0.000)$ & $<.0001$ & $<.0001$ & $(0.969)$ & $<.0001$ & $<.0001$ & $<.0001$ & $<.0001$ & $<.0001$ & $<.0001$ & $<.0001$ \\
\hline \multirow{2}{*}{ LEVERAGE $_{i t}(5)$} & - & - & - & - & -0.385 & 0.004 & -0.141 & -0.174 & -0.028 & 0.090 & -0.120 & 0.105 & 0.116 & 0.114 \\
\hline & - & - & - & - & $<.0001$ & $(0.717)$ & $<.0001$ & $<.0001$ & $(0.013)$ & $<.0001$ & $<.0001$ & $<.0001$ & $<.0001$ & $<.0001$ \\
\hline \multirow{2}{*}{$R O A_{i t}(6)$} & - & - & - & - & - & 0.204 & 0.388 & 0.239 & 0.358 & 0.055 & 0.257 & 0.005 & 0.042 & 0.038 \\
\hline & - & - & - & - & - & $<.0001$ & $<.0001$ & $<.0001$ & $<.0001$ & $<.0001$ & $<.0001$ & $(0.628)$ & $(0.000)$ & $(0.001)$ \\
\hline \multirow{2}{*}{ INVEST $_{i t}(7)$} & - & - & - & - & - & - & 0.038 & 0.062 & 0.442 & 0.387 & 0.106 & 0.058 & 0.071 & 0.067 \\
\hline & - & - & - & - & - & - & $(0.001)$ & $<.0001$ & $<.0001$ & $<.0001$ & $<.0001$ & $<.0001$ & $<.0001$ & $<.0001$ \\
\hline \multirow{2}{*}{$D A_{i t}(8)$} & - & - & - & - & - & - & - & -0.027 & 0.195 & 0.048 & -0.020 & -0.033 & -0.031 & -0.041 \\
\hline & - & - & - & - & - & - & - & $(0.018)$ & $<.0001$ & $<.0001$ & $(0.072)$ & $(0.003)$ & $(0.005)$ & $(0.000)$ \\
\hline \multirow{2}{*}{ CASHHOLDING ${ }_{i t}$ (9) } & - & - & - & - & - & - & - & - & 0.273 & 0.148 & 0.114 & -0.016 & -0.027 & -0.030 \\
\hline & - & - & - & - & - & - & - & - & $<.0001$ & $<.0001$ & $<.0001$ & $(0.164)$ & $(0.017)$ & $(0.008)$ \\
\hline \multirow{2}{*}{$G R W A_{i t}(10)$} & - & - & - & - & - & - & - & - & - & 0.735 & 0.0533 & -0.006 & 0.007 & 0.006 \\
\hline & - & - & - & - & - & - & - & - & - & $<.0001$ & $<.0001$ & $(0.572)$ & $(0.533)$ & $(0.585)$ \\
\hline \multirow{2}{*}{$G R W L_{i t}(11)$} & - & - & - & - & - & - & - & - & - & -- & 0.013 & -0.004 & -0.005 & -0.003 \\
\hline & - & - & - & - & - & - & - & - & - & - & $(0.266)$ & $(0.753)$ & $(0.629)$ & $(0.788)$ \\
\hline \multirow{2}{*}{$F O R_{i t}(12)$} & - & - & - & - & - & - & - & - & - & - & - & 0.271 & 0.297 & 0.301 \\
\hline & - & - & - & - & - & - & - & - & - & - & - & $<.0001$ & $<.0001$ & $<.0001$ \\
\hline \multirow{2}{*}{ OutsideDir $_{i t}(13)$} & - & - & - & - & - & - & - & - & - & - & - & - & 0.730 & 0.729 \\
\hline & - & - & - & - & - & - & - & - & - & - & - & - & $<.0001$ & $<.0001$ \\
\hline \multirow{2}{*}{ AuditCommittee $_{i t}(14)$} & - & - & - & - & - & - & - & - & - & - & - & - & - & 0.916 \\
\hline & - & - & - & - & - & - & - & - & - & - & - & - & - & $<.0001$ \\
\hline
\end{tabular}

\subsection{Main regression results}

Our first hypothesis examines the relationship between product market competition and corporate tax avoidance. Table 4 reports the OLS coefficient estimates for the regression model based on equation (2). Panel A and Panel B are the results for equation (2), where the dependent variable is the measure of tax avoidance estimated based on discretionary accruals and total accruals, respectively (TA1, TA2). In both panels, we observe negative and statistically significant coefficients on COMPETITION (-0.0190, $p$-value $=0.0248$; $-0.0226, p$-value $<0.01)$. Consistent with our prediction, these results indicate that there is a negative relationship between product market competition and both proxies for tax avoidance. Moreover, the control variables except for leverage have significant coefficients in explaining corporate tax avoidance. Therefore, these results indicate that product market competition effectively reduces tax avoidance activities as a method of managerial diversion for private gains.

Table 5 reports the results of regression equation (2) for two sub-samples: high board independence versus low board independence. We measure the board independence as the proportion of outside directors on the board and classify the firms with board independence above (below) the median as high (low) board independence group. Our second hypothesis predicts that the negative relationship between product market competition and tax avoidance will be more pronounced for high board independence group than low board independence group.

In Panel $A$, we present the results for equation (2), where the dependent variable is $T A 1$. The regression coefficient estimate of COMPETITION in high board independence group is significantly negative $(-0.0266$, $p$-value $=0.0209)$, whereas the 
Table 4. Product market competition and tax avoidance activities

\begin{tabular}{|c|c|c|c|c|}
\hline \multirow[t]{2}{*}{ Variable } & \multicolumn{2}{|c|}{$\begin{array}{c}\text { Panel } \mathrm{A} \text {. } \\
\text { Dependent variable }=T A 1 \\
\end{array}$} & \multicolumn{2}{|c|}{$\begin{array}{c}\text { Panel B. } \\
\text { Dependent variable }=T A 2\end{array}$} \\
\hline & Coef. & $p$-value & Coef. & $p$-value \\
\hline Intercept & 0.0167 & 0.2486 & 0.0222 & 0.1195 \\
\hline COMPETITION & -0.0190 & 0.0248 & -0.0226 & $<0.01$ \\
\hline SIZE & -0.0020 & $<0.01$ & -0.0019 & 0.0138 \\
\hline LEVERAGE $_{\text {it. }}$ & 0.0040 & 0.4593 & 0.0083 & 0.1288 \\
\hline $\mathrm{ROA}_{\mathrm{it} \ldots \ldots \ldots}$ & 0.4081 & $<0.01$ & 0.3680 & $<0.01$ \\
\hline INVEST & -0.0919 & $<0.01$ & -0.0685 & $<0.01$ \\
\hline DAit-1 & -0.2326 & $<0.01$ & -0.1484 & $<0.01$ \\
\hline CASHHOLDING & -0.1168 & $<0.01$ & -0.1107 & $<0.01$ \\
\hline GRWA & 0.2076 & $<0.01$ & 0.2004 & $<0.01$ \\
\hline $\mathrm{GRWL}_{\text {it... }}$ & -0.0582 & $<0.01$ & -0.0572 & $<0.01$ \\
\hline $\mathrm{FOR}_{\mathrm{it}, \ldots}$ & -0.0196 & 0.0341 & -0.0002 & 0.0771 \\
\hline Industry fixed effect & \multicolumn{2}{|c|}{ Yes } & \multicolumn{2}{|c|}{ Yes } \\
\hline Year fixed effect & \multicolumn{2}{|c|}{ Yes } & \multicolumn{2}{|c|}{ Yes } \\
\hline Firm clustering & \multicolumn{2}{|c|}{ Yes } & \multicolumn{2}{|c|}{ Yes } \\
\hline Adj. $R^{2}$ & \multicolumn{2}{|c|}{0.3451} & \multicolumn{2}{|c|}{0.3056} \\
\hline $\mathrm{N}$ & \multicolumn{2}{|c|}{7.918} & \multicolumn{2}{|c|}{7.918} \\
\hline
\end{tabular}

Notes: The standard errors are adjusted for firm level clustering. Variables are as defined in Table 2. All $p$-values are based on two-tailed tests.

one in low board independence group is not statistically significant $(-0.0009, p$-value $=0.9299)$. Panel B presents the results for equation (2), where the dependent variable is TA2. In high board independence group, the coefficient of COMPETITION is significant and negative $(-0.0295, p$-value $<0.01)$. However, in low board independence group, COMPETITION has an insignificant coefficient $(-0.0064, p$-value $=0.5330)$. Untabulated test results show that the coefficients of COMPETITION are significantly different between two sub-groups when using TA1 and TA2 as the dependent variable $(p$-value $=0.0398, p$-value $=0.0533)$. Hence, product market competition is interpreted to regulate the market for firms with independent board of directors in order to reduce tax avoidance as an external governance mechanism.

Panel A of Table 6 reports the results of regression equation (2) for two sub-samples: firms with

Table 5. The effect of board independence on the relationship between product market competition and tax avoidance activities

\begin{tabular}{|c|c|c|c|c|c|c|c|c|}
\hline \multirow{3}{*}{ Variable } & \multicolumn{4}{|c|}{ Dependent variable $=T A 1$} & \multicolumn{4}{|c|}{ Dependent variable $=$ TA2 } \\
\hline & \multicolumn{2}{|c|}{$\begin{array}{c}\text { High board } \\
\text { independence group }\end{array}$} & \multicolumn{2}{|c|}{$\begin{array}{c}\text { Low board } \\
\text { independence group }\end{array}$} & \multicolumn{2}{|c|}{$\begin{array}{c}\text { High board } \\
\text { independence group }\end{array}$} & \multicolumn{2}{|c|}{$\begin{array}{c}\text { Low board } \\
\text { independence group }\end{array}$} \\
\hline & Coef. & $p$-value & Coef. & $p$-value & Coef. & $p$-value & Coef. & $p$-value \\
\hline Intercept & 0.0096 & 0.5628 & 0.0545 & 0.0207 & 0.0188 & 0.2639 & 0.0577 & 0.0125 \\
\hline COMPETITION & -0.0266 & 0.0209 & -0.0009 & 0.9299 & -0.0295 & $<0.01$ & -0.0064 & 0.5330 \\
\hline $\mathrm{SIZE}_{\mathrm{it} \ldots}$ & -0.0017 & 0.0538 & -0.0043 & $<0.01$ & -0.0016 & 0.0676 & -0.0037 & $<0.01$ \\
\hline LEVERAGE $_{\text {it... }}$ & -0.0016 & 0.8292 & 0.0060 & 0.4357 & 0.0038 & 0.6194 & 0.0098 & 0.1960 \\
\hline $\mathrm{ROA}_{\text {it }}$ & 0.3962 & $<0.01$ & 0.4224 & $<0.01$ & 0.3595 & $<0.01$ & 0.3775 & $<0.01$ \\
\hline INVEST & -0.1000 & $<0.01$ & -0.0795 & 0.0145 & -0.0617 & 0.0437 & -0.0722 & 0.0247 \\
\hline DAit-1 & -0.2329 & $<0.01$ & -0.2347 & $<0.01$ & -0.1482 & $<0.01$ & -0.1507 & $<0.01$ \\
\hline CASHHOLDING $_{\text {it }}$ & -0.1265 & $<0.01$ & -0.1020 & $<0.01$ & -0.1299 & $<0.01$ & -0.0816 & $<0.01$ \\
\hline GRWA & 0.2137 & $<0.01$ & 0.2025 & $<0.01$ & 0.2039 & $<0.01$ & 0.1976 & $<0.01$ \\
\hline $\mathrm{GRWL}_{\mathrm{jt}}$ & -0.0532 & $<0.01$ & -0.0640 & $<0.01$ & -0.0534 & $<0.01$ & -0.0616 & $<0.01$ \\
\hline FOR $_{\text {it }}$ & -0.0204 & 0.0503 & -0.0209 & 0.1275 & -0.0170 & 0.1049 & -0.0195 & 0.1457 \\
\hline Industry fixed effect & \multicolumn{2}{|c|}{ Yes } & \multicolumn{2}{|c|}{ Yes } & \multicolumn{2}{|c|}{ Yes } & \multicolumn{2}{|c|}{ Yes } \\
\hline Year fixed effect & \multicolumn{2}{|c|}{ Yes } & \multicolumn{2}{|c|}{ Yes } & \multicolumn{2}{|c|}{ Yes } & \multicolumn{2}{|c|}{ Yes } \\
\hline Firm clustering & \multicolumn{2}{|c|}{ Yes } & \multicolumn{2}{|c|}{ Yes } & \multicolumn{2}{|c|}{ Yes } & \multicolumn{2}{|c|}{ Yes } \\
\hline Adj. $R^{2}$ & \multicolumn{2}{|c|}{0.3521} & \multicolumn{2}{|c|}{0.3458} & \multicolumn{2}{|c|}{0.3117} & \multicolumn{2}{|c|}{0.2641} \\
\hline $\mathrm{N}$ & \multicolumn{2}{|c|}{4.551} & \multicolumn{2}{|c|}{3.367} & \multicolumn{2}{|c|}{4.551} & \multicolumn{2}{|c|}{3.367} \\
\hline
\end{tabular}

Notes: The standard errors are adjusted for firm level clustering. Variables are as defined in Table 2. All $p$-values are based on two-tailed tests. 
audit committee and firms without audit committee. In the left-side column, we present the results for equation (2), where the dependent variable is $T A 1$. The regression coefficient estimate of COMPETITION for firms with audit committee is significantly negative $(-0.0257, p$-value $=0.0313)$, whereas the one for firms without audit commit- tee is not statistically significant $(-0.0088, p$-value $=0.3715$ ). The right-side column presents the results for equation (2), where the dependent variable is TA2. In a sample of firms with audit committee, the coefficient of COMPETITION is significant and negative $(-0.0315, p$-value $<0.01)$. However, in a sample of firms without audit committee,

Table 6. The effect of audit committee on the relationship between product market competition and tax avoidance activities

Panel A. Audit committee

\begin{tabular}{|c|c|c|c|c|c|c|c|c|}
\hline \multirow{3}{*}{ Variable } & \multicolumn{4}{|c|}{ Dependent variable $=$ TA1 } & \multicolumn{4}{|c|}{ Dependent variable = TA2 } \\
\hline & \multicolumn{2}{|c|}{ With audit committee } & \multicolumn{2}{|c|}{$\begin{array}{c}\text { Without audit } \\
\text { committee }\end{array}$} & \multicolumn{2}{|c|}{ With audit committee } & \multicolumn{2}{|c|}{$\begin{array}{c}\text { Without audit } \\
\text { committee }\end{array}$} \\
\hline & Coef. & $p$-value & Coef. & $p$-value & Coef. & $p$-value & Coef. & $p$-value \\
\hline Intercept & -0.0146 & 0.5096 & 0.0838 & $<0.01$ & -0.0060 & 0.7950 & 0.0906 & $<0.01$ \\
\hline COMPETITION & -0.0257 & 0.0313 & -0.0088 & 0.3715 & -0.0315 & $<0.01$ & -0.0120 & 0.2232 \\
\hline $\mathrm{SIZE}_{\mathrm{it} \ldots \ldots}$ & -0.0001 & 0.9009 & -0.0057 & $<0.01$ & -0.0001 & 0.9264 & -0.0053 & $<0.01$ \\
\hline LEVERAGE $_{\text {it. }}$ & -0.0047 & 0.6778 & -0.0017 & 0.7801 & 0.0002 & 0.9865 & 0.0028 & 0.6441 \\
\hline $\mathrm{ROA}_{\mathrm{it}} \ldots \ldots$ & 0.3649 & $<0.01$ & 0.4285 & $<0.01$ & 0.3353 & $<0.01$ & 0.3858 & $<0.01$ \\
\hline INVEST $_{\text {it.. }}$ & -0.0601 & 0.1703 & -0.1031 & $<0.01$ & -0.0270 & 0.5428 & -0.0816 & $<0.01$ \\
\hline DAit-1 & -0.2572 & $<0.01$ & -0.2256 & $<0.01$ & -0.1612 & $<0.01$ & -0.1447 & $<0.01$ \\
\hline CASHHOLDING & -0.1514 & $<0.01$ & -0.1028 & $<0.01$ & -0.1455 & $<0.01$ & -0.0980 & $<0.01$ \\
\hline GRWA $_{\text {it }}$ & 0.2401 & $<0.01$ & 0.2000 & $<0.01$ & 0.2383 & $<0.01$ & 0.1906 & $<0.01$ \\
\hline $\mathrm{GRWL}_{\mathrm{it} .}$ & -0.0750 & $<0.01$ & -0.0530 & $<0.01$ & -0.0775 & $<0.01$ & -0.0509 & $<0.01$ \\
\hline $\mathrm{FOR}_{\mathrm{jt}}$ & -0.0441 & $<0.01$ & -0.0117 & 0.2653 & -0.0429 & $<0.01$ & -0.0089 & 0.3796 \\
\hline $\begin{array}{l}\text { Industry fixed } \\
\text { effect }\end{array}$ & \multicolumn{2}{|c|}{ Yes } & \multicolumn{2}{|c|}{ Yes } & \multicolumn{2}{|c|}{ Yes } & \multicolumn{2}{|c|}{ Yes } \\
\hline Year fixed effect & \multicolumn{2}{|c|}{ Yes } & \multicolumn{2}{|c|}{ Yes } & \multicolumn{2}{|c|}{ Yes } & \multicolumn{2}{|c|}{ Yes } \\
\hline Firm clustering & \multicolumn{2}{|c|}{ Yes } & \multicolumn{2}{|c|}{ Yes } & \multicolumn{2}{|c|}{ Yes } & \multicolumn{2}{|c|}{ Yes } \\
\hline Adj. $R^{2}$ & \multicolumn{2}{|c|}{0.3855} & \multicolumn{2}{|c|}{0.3423} & \multicolumn{2}{|c|}{0.3523} & \multicolumn{2}{|c|}{0.3009} \\
\hline $\mathrm{N}$ & \multicolumn{2}{|c|}{2.162} & \multicolumn{2}{|c|}{5.756} & \multicolumn{2}{|c|}{2.162} & \multicolumn{2}{|c|}{5.756} \\
\hline
\end{tabular}

Notes: The standard errors are adjusted for firm level clustering. Variables are as defined in Table 2 . All $p$-values are based on two-tailed tests.

Panel B. Audit committee independence

\begin{tabular}{|c|c|c|c|c|c|c|c|c|}
\hline \multirow{3}{*}{ Variable } & \multicolumn{4}{|c|}{ Dependent variable $=$ TA1 } & \multicolumn{4}{|c|}{ Dependent variable $=T A 2$} \\
\hline & \multicolumn{2}{|c|}{$\begin{array}{l}\text { High audit committee } \\
\text { independence group }\end{array}$} & \multicolumn{2}{|c|}{$\begin{array}{l}\text { Low audit committee } \\
\text { independence group }\end{array}$} & \multicolumn{2}{|c|}{$\begin{array}{l}\text { High audit committee } \\
\text { independence group }\end{array}$} & \multicolumn{2}{|c|}{$\begin{array}{l}\text { Low audit committee } \\
\text { independence group }\end{array}$} \\
\hline & Coef. & $p$-value & Coef. & $p$-value & Coef. & $p$-value & Coef. & $p$-value \\
\hline Intercept & 0.0076 & 0.7620 & 0.0707 & $<0.01$ & 0.0181 & 0.4819 & 0.0775 & $<0.01$ \\
\hline COMPETITION & -0.0233 & 0.0599 & -0.0098 & 0.3049 & -0.0301 & 0.0117 & -0.0128 & 0.1824 \\
\hline $\mathrm{SIZE}_{\mathrm{it}}$ & -0.0011 & 0.4006 & -0.0050 & $<0.01$ & -0.0011 & 0.3718 & -0.0047 & $<0.01$ \\
\hline LEVERAGE $_{\text {it. }}$ & -0.0100 & 0.4073 & 0.0005 & 0.9365 & -0.0055 & 0.6445 & 0.0051 & 0.3924 \\
\hline $\mathrm{ROA}_{\text {it }}$ & 0.3344 & $<0.01$ & 0.4337 & $<0.01$ & 0.3017 & $<0.01$ & 0.3918 & $<0.01$ \\
\hline INVEST & -0.0516 & 0.2628 & -0.1050 & $<0.01$ & -0.0181 & 0.6989 & -0.0825 & $<0.01$ \\
\hline DAit-1 & -0.2523 & $<0.01$ & -0.2261 & $<0.01$ & -0.1519 & $<0.01$ & -0.1455 & $<0.01$ \\
\hline CASHHOLDING & -0.1730 & $<0.01$ & -0.1011 & $<0.01$ & -0.1652 & $<0.01$ & -0.0960 & $<0.01$ \\
\hline GRWA $_{\text {it }}$ & 0.2591 & $<0.01$ & 0.1973 & $<0.01$ & 0.2574 & $<0.01$ & 0.1881 & $<0.01$ \\
\hline $\mathrm{GRWL}_{\mathrm{it.}}$ & -0.0846 & $<0.01$ & -0.0517 & $<0.01$ & -0.0870 & $<0.01$ & -0.0498 & $<0.01$ \\
\hline $\mathrm{FOR}_{\mathrm{it} \ldots \ldots}$ & -0.0367 & 0.0201 & -0.0161 & 0.1229 & -0.0353 & 0.0290 & -0.0130 & 0.2000 \\
\hline $\begin{array}{l}\text { Industry fixed } \\
\text { effect }\end{array}$ & \multicolumn{2}{|c|}{ Yes } & \multicolumn{2}{|c|}{ Yes } & \multicolumn{2}{|c|}{ Yes } & \multicolumn{2}{|c|}{ Yes } \\
\hline Year fixed effect & \multicolumn{2}{|c|}{ Yes } & \multicolumn{2}{|c|}{ Yes } & \multicolumn{2}{|c|}{ Yes } & \multicolumn{2}{|c|}{ Yes } \\
\hline Firm clustering & \multicolumn{2}{|c|}{ Yes } & \multicolumn{2}{|c|}{ Yes } & \multicolumn{2}{|c|}{ Yes } & \multicolumn{2}{|c|}{ Yes } \\
\hline Adj. $R^{2}$ & \multicolumn{2}{|c|}{0.3919} & \multicolumn{2}{|c|}{0.3433} & \multicolumn{2}{|c|}{0.3576} & \multicolumn{2}{|c|}{0.3025} \\
\hline $\mathrm{N}$ & \multicolumn{2}{|c|}{1.898} & \multicolumn{2}{|c|}{6.020} & \multicolumn{2}{|c|}{1.898} & \multicolumn{2}{|c|}{6.020} \\
\hline
\end{tabular}

Notes: The standard errors are adjusted for firm level clustering. Variables are as defined in Table 2 . All $p$-values are based on two-tailed tests. 
Table 7. The effect of foreign investors on the relationship between product market competition and tax avoidance activities

\begin{tabular}{|c|c|c|c|c|c|c|c|c|}
\hline \multirow{3}{*}{ Variable } & \multicolumn{4}{|c|}{ Dependent variable $=T A 1$} & \multicolumn{4}{|c|}{ Dependent variable $=T A 2$} \\
\hline & \multicolumn{2}{|c|}{ High foreign ownership } & \multicolumn{2}{|c|}{ Low foreign ownership } & \multicolumn{2}{|c|}{ High foreign ownership } & \multicolumn{2}{|c|}{ Low foreign ownership } \\
\hline & Coef. & $p$-value & Coef. & $p$-value & Coef. & $p$-value & Coef. & $p$-value \\
\hline Intercept & -0.0076 & 0.6646 & 0.0482 & 0.0578 & 0.0087 & 0.6145 & 0.0768 & $<0.01$ \\
\hline COMPETITION & -0.0231 & 0.0259 & -0.0184 & 0.0917 & -0.0272 & $<0.01$ & -0.0198 & 0.0753 \\
\hline $\mathrm{SIZE}_{\mathrm{jt}}$ & -0.0007 & 0.4712 & -0.0038 & $<0.01$ & -0.0011 & 0.1965 & -0.0047 & $<0.01$ \\
\hline LEVERAGE $_{\text {it }}$ & -0.0035 & 0.6760 & 0.0043 & 0.5211 & 0.0039 & 0.6325 & 0.0083 & 0.2223 \\
\hline $\mathrm{ROA}_{\mathrm{it}}$ & 0.2668 & $<0.01$ & 0.5096 & $<0.01$ & 0.2323 & $<0.01$ & 0.4645 & $<0.01$ \\
\hline INVEST $_{\text {it... }}$ & -0.0963 & $<0.01$ & -0.0871 & $<0.01$ & -0.0595 & 0.0450 & -0.0800 & 0.0118 \\
\hline DAit-1 & -0.2352 & $<0.01$ & -0.2438 & $<0.01$ & -0.1321 & $<0.01$ & -0.1725 & $<0.01$ \\
\hline CASHHOLDING & -0.0907 & $<0.01$ & -0.1311 & $<0.01$ & -0.0838 & $<0.01$ & -0.1297 & $<0.01$ \\
\hline GRWA $_{\text {it }}$ & 0.2264 & $<0.01$ & 0.1968 & $<0.01$ & 0.2235 & $<0.01$ & 0.1905 & $<0.01$ \\
\hline $\mathrm{GRWL}_{\mathrm{it}}$ & -0.0638 & $<0.01$ & -0.0534 & $<0.01$ & -0.0664 & $<0.01$ & -0.0505 & $<0.01$ \\
\hline Industry fixed effect & \multicolumn{2}{|c|}{ Yes } & \multicolumn{2}{|c|}{ Yes } & \multicolumn{2}{|c|}{ Yes } & \multicolumn{2}{|c|}{ Yes } \\
\hline Year fixed effect & \multicolumn{2}{|c|}{ Yes } & \multicolumn{2}{|c|}{ Yes } & \multicolumn{2}{|c|}{ Yes } & \multicolumn{2}{|c|}{ Yes } \\
\hline Firm clustering & \multicolumn{2}{|c|}{ Yes } & \multicolumn{2}{|c|}{ Yes } & \multicolumn{2}{|c|}{ Yes } & \multicolumn{2}{|c|}{ Yes } \\
\hline Adj. $R^{2}$ & \multicolumn{2}{|c|}{0.3073} & \multicolumn{2}{|c|}{0.3929} & \multicolumn{2}{|c|}{0.265} & \multicolumn{2}{|c|}{0.3519} \\
\hline N & \multicolumn{2}{|c|}{3.961} & \multicolumn{2}{|c|}{3.957} & \multicolumn{2}{|c|}{3.961} & \multicolumn{2}{|c|}{3.957} \\
\hline
\end{tabular}

Notes: The standard errors are adjusted for firm level clustering. Variables are as defined in Table 2. All $p$-values are based on two-tailed tests.

COMPETITION has an insignificant coefficient $(-0.0120, p$-value $=0.2232)$. Untabulated test results show that the coefficients of COMPETITION are significantly different between two sub-groups when using TA1 and TA2 as the dependent variable $(p$-value $=0.0314, p$-value $=0.0335)$.

Panel B of Table 6reports the results of regression equation (2) for two sub-samples: high audit committee independence and low audit committee independence groups. We define audit committee to be highly independent when all committee members are outside directors. When the dependent variable is $T A 1$, the regression coefficient estimate of COMPETITION for high audit committee independence group is significantly negative $(-0.0233, p$-value $=0.0599)$, whereas the one for firms with low audit committee independence is not statistically significant $(-0.0098, p$-value $=0.3049)$. Also, we use TA2 as the dependent variable. In a sample of firms with high audit committee independence, the coefficient of COMPETITION is significant and negative $(-0.0301, p$-value $=0.0117)$. However, when firms have low audit committee independence, COMPETITION has an insignificant coefficient $(-0.0128, p$-value $=0.1824)$. Untabulated test results show that the coefficients of COMPETITION are significantly different between two sub- groups when using TA1 and TA2 as the dependent variable $(p$-value $=0.0696, p$-value $=0.0647)$.

These findings indicate that the presence and independence of audit committee are necessary in order for product market competition to work effectively as an external corporate governance mechanism in monitoring tax avoidance activities.

Table 7 presents the regression results that examine the effects of foreign investor ownership on the relationship between product market competition and tax avoidance. First, we report the results when using TA1 as the dependent variable. We discover that COMPETITION has a significantly negative coefficient in high foreign equity ownership group $(-0.0231, p$-value $=0.0259)$, as well as in low foreign equity ownership group $(-0.0184$, $p$-value $=0.0917)$. These coefficients are not statistically different ( $p$-value $=0.8405$ ). When using TA2 as the dependent variable, COMPETITION has a significantly negative coefficient in high foreign equity ownership group $(-0.0272, p$-value $<0.01)$, as well as in low foreign equity ownership group $(-0.0198, p$-value $=0.0753)$. These coefficients are not statistically different ( $p$-val$\mathrm{ue}=0.9153$ ). Hence, these results indicate that foreign investors' equity ownership does not play an effective monitoring role in reducing tax avoidance for firms that face product market competition. 


\section{SUMMARY AND CONCLUSION}

This paper examines the effect of product market competition on corporate tax avoidance. Furthermore, we investigate how the relationship between product market competition and tax avoidance is affected by corporate governance.

We observe a negative association between product market competition and tax avoidance, which implies that market competition regulates managers to reduce tax avoidance. Moreover, we find that product market competition works more effectively as an external corporate governance mechanism in firms with more independent directors on the board, firms with audit committee, and firms with independent audit committee. These results indicate that the interaction between external and internal corporate governance mechanisms influences the level of corporate tax avoidance.

This study provides new evidence on the effect of industry-wide factors such as product market competition on corporate tax avoidance activities, whereas previous studies have focused on firm-specific characteristics as the determinants of corporate tax avoidance. Furthermore, our results may be of interest to policy makers and regulators, since they directly demonstrate the effect of high market competition on corporate tax avoidance.

\section{REFERENCES}

1. Allen, F., \& Gale, D. (2000). Corporate Governance and Competition. In Corporate Governance: Theoretical and Empirical perspectives (pp. 23-94) Cambridge University Press.

2. Armstrong, C. S., Blouin, J. L., \& Larcker, D. F. (2012). The incentives for tax planning. Journal of Accounting and Economics, 53(1-2), 391-411. https://doi.org/10.1016/j. jacceco.2011.04.001

3. Bae, K., Kang, J., \& Kim, J. (2002). Tunneling or value added? Evidence from mergers by Korean business groups. Journal of Finance, 57(6), 2695-2740. https://doi. org/10.1111/1540-6261.00510

4. Black, B., Jang, H., \& Kim, W. (2006). Predicting Firms' Corporate Governance Choices: Evidence from Korea. Journal of Corporate Finance, 12(3), 660-691. https://doi org/10.1016/j.jcorpfin.2005.08.001

5. Byun, H. S., Lee, J. H., \& Park, K. S. (2012). How Does Product Market Competition Interact with Internal Corporate Governance? Evidence from the Korean Economy. Asia-Pacific. Journal of Financial Studies, 41(4), 377-423. https://doi.org/10.1111/j.20416156.2012.01077.x

6. Datta, S., Iskandar-Datta, M., \& Singh, V. (2013). Product market power, industry structure, and corporate earnings management. Journal of Banking and Finance, 37(8), 3273-3285. https://doi. org/10.1016/j.jbankfin.2013.03.012

7. Desai, M. A., \& Dharmapala, D. (2009). Corporate tax avoidance and firm value. The Review of Economics and Statistics, 91(3), 537 546. Retrieved from https://www. nber.org/papers/w11241

8. Desai, M. A., Dyck, A., \& Zingales, L. (2004). Corporate governance and taxation. In American Law \& Economics Association Annual Meetings (p. 75).

9. Desai, M., \& Dharmapala, D. (2006). Corporate Tax Avoidance and High-powered Incentives. Journal of Financial Economics, 79(1), 145-179. https://doi. org/10.1016/j.jfineco.2005.02.002

10. Desai, M., Dyck, I., \& Zingales, L. (2007). Theft and taxes. Journal of Financial Economics, 84(3), 591-623. https://doi.org/10.1016/j. jineco.2006.05.005

11. Dyreng, S., Hanlon, M., \& Maydew, E. (2008). Long-Run Corporate Tax Avoidance. The Accounting Review, 83(1), 61-82. Retrieved from https://www.jstor.org/ stable/30243511?seq=1\#page_scan_ tab contents
12. Fama, E. (1980). Agency Problems and The Theory of The Firm. Journal of Political Economy, 88(2), 288-307. http://dx.doi. org/10.1086/260866

13. Fama, E., \& Jensen, M. (1983). Separation of Ownership and Control. Journal of Law and Economic, 26, 301-325.

14. Frank, M. M., Lynch, L., \& Rego, S. (2009). Tax reporting aggressiveness and its relation to aggressive financial reporting. The Accounting Review, 84(2), 467-496. Retrieved form https://www.jstor. org/stable/27802660?seq=1\#page scan_tab_contents

15. Griffith, R. (2001). Product Market Competition, Efficiency and Agency Cost: An Empirical Analysis (Institute for Fiscal Studies Working Paper).

16. Grullon, G., \& Michaely, R. (2007). Corporate Payout Policy and Product Market Competition (Working Paper). http://dx.doi. org/10.2139/ssrn.972221

17. Hanlon, M., \& Heitzman, S. (2010) A review of tax research. Journal of Accounting and Economics, 50(2-3), 127-178. https://doi.org/10.1016/j. jacceco.2010.09.002

18. Hart, O. (1983). The Market Mechanism as an Incentive 
Scheme. Bell Journal of Economics, 14(2), 366-382. https://doi. org/10.2307/3003639

19. Haushalter, D., Klasa, S., \& Maxwell, W. (2006). The Influence of Product Market Dynamics on a Firm's Cash Holdings and Hedging Behavior. Journal of Financial Economics, 84(3), 797-825. https://doi. org/10.1016/j.jineco.2006.05.007

20. Jensen, M. C., \& Meckling, W. H. (1992). Theory of the Firm: Managerial Behavior, Agency Costs and Ownership Structure. Journal of Financial Economics, 3(4), 305360. https://doi.org/10.1016/0304405X(76)90026-X

21. La Porta, R., Lopez-de-Silanes, F., Shleifer, A., \& Vishny, R. (2000). Agency Problem and Dividend Policies around the World. Journal of Finance, 55(1), 1-33. https://doi. org/10.1111/0022-1082.00199

22. Lemmon, L., \& Lin, K. (2003). Ownership Structure, Corporate Governance, and Firm Value: Evidence from East Asian Financial Crisis. Journal of Finance, 58(4), 1445-1468. https://doi. org/10.1111/1540-6261.00573

23. Manzon, G., \& Plesko, G. A. (2002). The Relation Between Financial and Tax Reporting Measures of Income. Tax Law Review, 55(2), 175-214.
24. McGuire, S. T., Wang, D., \& Wilson, R. J. (2014). Dual Class Ownership and Tax Avoidance. The Accounting Review, 89(4), 1487-1516. Retrieved from https://papers.ssrn.com/sol3/ papers.cfm?abstract_id=1761994

25. Park, K. S., Byun, H. S., \& Lee, J. H. (2011). Study on the Interaction of Product Market Competition and Internal Corporate Governance on Corporate Payout Policy and Investment Decision. Asian Review of Financial Research, 24(2), 483523

26. Petersen, M. A. (2009). Estimating standard errors in finance panel data sets: Comparing approaches. Review of Financial Studies, 22(1), 435-480. Retrieved from https:// www.nber.org/papers/w11280

27. Porter, M. (1980). Competitive Strategy. New York: Free Press.

28. Rego, S. O., \& Wilson, R. (2012). Equity risk incentives and corporate tax aggressiveness. Journal of Accounting Research, 50, 775-810. https://doi.org/10.1111/ j.1475-679X.2012.00438.x

29. Rumelt, R. (1991). How Much Does Industry Matter? Strategic Management Journal, 12(3), 167185. Retrieved from https://www.jstor.org/stable/2486591? seq=1\#page scan_tab_contents
30. Schmidt, K. (1997). Managerial Incentives and Product Market Competition. Review of Economic Studies, 64(2), 191-213. https://doi. org/10.2307/2971709

31. Shin, I. H., Lee, M. G., \& Lee, E. C. (2014). Market Competition and Real Earnings Management: Focusing on Interaction with Corporate Governance. Korean Accounting Review, 39(3), 57-90.

32. Shleifer, A., \& Vishny, R. (1997). A Survey of Corporate Governance. Journal of Finance, 52(2), 737-783. Retrieved from https://scholar. harvard.edu/shleifer/publications/ survey-corporate-governance

33. Slemrod, J. (2007). Cheating ourselves: The economics of tax evasion. The Journal of Economic Perspectives, 25-48. Retrieved from https://www.aeaweb.org/ articles?id=10.1257/jep.21.1.25

34. Song, G. S. (2013). The Association Between Managerial Ownership and Discretionary Accruals, and Market Competition Effects. Korea Management Review, 42(6), 15891627.

35. Wilson, R. J. (2009). An examination of corporate tax shelter participants. The Accounting Review, 84(3), 969-999. https://doi. org/10.2308/accr.2009.84.3.969

\section{APPENDIX. VARIABLE DEFINITION}

\begin{tabular}{|c|c|}
\hline Variable & Description \\
\hline COMPETITION & $\begin{array}{l}\text { Our primary measure of product market competition, based on the Herfindhal-Hirschman Index. } \\
\text { It is measured as } \\
\text { Where } x_{i} \text { is the market share of sales for firm } i \text { among all firms within the same industry. A higher value of } \\
\text { COMPETITION indicates less concentrated industries, or more competition among firms in the same industry }\end{array}$ \\
\hline TA1 & $\begin{array}{l}\text { Tax avoidance proxies based on Desai and Dharmapala (2006) when discretionary accruals is used for } \\
\text { earnings management }\end{array}$ \\
\hline TA2 & $\begin{array}{l}\text { Tax avoidance proxies based on Desai and Dharmapala (2006) when total accruals is used for earnings } \\
\text { management }\end{array}$ \\
\hline SIZE & The logarithm of total assets \\
\hline LEVERAGE & Total liabilities divided by total assets \\
\hline ROA & Net income divided by beginning total assets \\
\hline INVEST & (Change in PPE excluding land + Depreciation + R\&D expenditures) divided by beginning total assets \\
\hline DA & discretionary accruals (scaled by beginning total assets) based on Kothari (2005) \\
\hline CASHHOLDING & (Cash and cash equivalents + Short-term investments) divided by beginning total assets \\
\hline GRWA & The growth rates in total assets relative to prior year \\
\hline GRWL & The growth rates in total liabilities relative to prior year \\
\hline FOR & The proportion of ownership held by foreign investors \\
\hline OutsideDir & The proportion of outside directors in board of directors \\
\hline AuditCommittee $_{i t \ldots . .}$ & 1 if the audit committee exists, 0 otherwise \\
\hline AuditCom_indepen ${ }_{\text {it }}$ & 1 if the audit committee consists of $100 \%$ outside directors, 0 otherwise \\
\hline
\end{tabular}

